\title{
Strategically Investing in Health Research: The Little-Big Program Called RPP
}

\section{Investissement stratégique dans la recherche en santé : un grand petit programme nommé PPR}

\author{
ॠु \\ PENNY MOODY-CORBETT, PHD \\ Adjunct Professor, Division of BioMedical Sciences \\ Faculty of Medicine, Memorial University of Newfoundland \\ St. John's, NL
}

\begin{abstract}
The Regional Partnerships Program (RPP) was a program of the Canadian Institutes of Health Research (CIHR) and six provinces - Saskatchewan, Manitoba, New Brunswick, Nova Scotia, Prince Edward Island, and Newfoundland and Labrador. CIHR and each province contributed $50 \%$ to support health research that was recommended for funding by peer review but fell below the CIHR budgetary cut-off for funding. The provinces would like to commend CIHR for this strategic initiative and highlight the impact that small investment like RPP has had on engaging these provinces in the health research enterprise and expanding health research and its benefits across the country.

\section{Résumé}

Le Programme de partenariats régionaux (PPR) est une initiative des Instituts de recherche en santé du Canada (IRSC) et de six provinces - la Saskatchewan, le Manitoba, le NouveauBrunswick, la Nouvelle-Écosse, l'Île-du-Prince-Édouard et Terre-Neuve-et-Labrador. Dans le cadre de ce programme, les IRSC et chaque province apportent $50 \%$ en appui à des projets de
\end{abstract}


recherche recommandés pour un financement après examen par les pairs, mais qui se situent en deçà du seuil de financement des IRSC. Les provinces félicitent les IRSC pour cette initiative stratégique et tiennent à souligner l'impact de petits investissements comme ceux du PPR, que ce soit pour leur apport aux projets de recherche des provinces ou pour l'élan qu'ils donnent à la recherche en santé et ses bénéfices partout au pays.

I N i997, Canada's Medical Research Council (MRC) established a Regional Partnerships Program (RPP) to address the distribution of medical research funds across four provinces - Saskatchewan, Manitoba, Nova Scotia, and Newfoundland and Labrador (all with medical schools) - in response to a decline in funding compared to the other provinces (British Columbia, Alberta, Ontario and Quebec) that were home to Canadian medical schools.

With the change from MRC to the Canadian Institutes of Health Research (CIHR) on the heels of the CIHR Act in 2000, RPP was expanded to include New Brunswick and Prince Edward Island, provinces in which such research was underrepresented. After 16 years and less than $\$ 70$ million of investment from the federal health research granting agencies (MRC and CIHR), RPP has changed the landscape of health research. In the six RPP provinces, it has provided support for research initiatives that have had an impact on patient care, trained highly qualified health research professionals and advanced health research. Furthermore, RPP has contributed to CIHR's mandate of improved health for Canadians, more effective health services and products and a strengthened Canadian healthcare system, through exercising leadership within the Canadian research community and fostering collaboration with the provinces. Although the final funding opportunity for RPP was in spring 2013, the impact of this program and the research it has supported will continue.

In 2004-2005, CIHR commissioned an in-depth review of RPP, which documented the positive influence of investment on health research outcomes and encouraged the continuation of the program (CIHR 2007). At that time CIHR decided to continue the program for an additional two years and to consider a renewed program design within one year (CIHR 2007). However, since then CIHR has undergone a multi-year review of all funding programs and has undertaken a substantial change in the program funding design (CIHR 2014). Although partnership programming continues to be a major focus for the organization, CIHR decided to sunset this particular partnership program (CIHR 2013). This paper provides a brief commentary on the value of RPP from the perspectives of the six RPP provinces, garnered from recent conversations with individuals in each province who have been instrumental in administering the program in their jurisdictions. The program serves as a model of how small, strategic investment and collaboration with partners has had an impact on health research, its outcomes and the engagement of the health research community across the country. 


\section{What Is RPP?}

RPP was established to enhance health research in provinces with medical schools, where there was a continuing decline in research funding. The program required that each of the provinces establish a local advisory committee to oversee this funding opportunity and set priorities for health research. Research grants were submitted to the federal funding agency for peer review; those that ranked within the fundable range but below the budgetary cut-off for funding were eligible to receive financial support through RPP. Funding was arranged through a partnership in which the federal granting agency provided $50 \%$ of the value of the grant or award and provincial sources were responsible for the matching funds. Since $1999^{1}$ the investment per year for RPP has been $\$ 4.4$ million from the federal granting agency, with the partners providing at least a $\$ 4.4$-million match. Each province, through its advisory committee, ensured that research funding supported regional health research priorities. Each province determined which programs would be supported from the suite of those that were eligible (new and renewal operating grants, training and salary awards), and no RPP recipients were eligible to receive repeat funding on back-to-back grants.

\section{What Has RPP Meant for the Provinces?}

RPP has had obvious advantages for each grant or award recipient. Details on the number of award holders and the impact of RPP funding on research programs, personnel and future funding opportunities are available from the summative evaluation conducted in 2005 (CIHR 2007). The program has also benefited the provinces in meaningful ways, as highlighted below.

+ For each of the RPP provinces, the program has resulted in the development of relationships with provincial government departments involved in health research and innovation. In bringing together key stakeholders among the provincial governments, decision-makers, funding organizations, researchers and users of research, the program has involved the provinces in the role of health research in implementing changes in healthcare and contributing to their economic base through capacity development.

+ RPP has been important in providing bridge funding for new and established investigators to initiate and maintain internationally competitive research programs and continue to contribute to the health research knowledge base. The program has been instrumental in the research careers of some of Canada's top health research scholars. A number of RPP recipients have gone on to earn senior Canada Research Chairs and prestigious awards and honours in their fields, or have taken leadership roles in their academic careers (CIHR 2007, 2009). Accomplishments such as these are achieved as a result of long-term demonstration of successful research. Opportunities such as RPP have contributed by supporting research programs that might otherwise have been significantly disrupted.

- The provinces have been able to build health research capacity and contribute to their economic base through education and innovation. In each province, RPP has contrib- 
uted to funding trainees, either directly or through operating grant support, thereby enhancing the health research base. Although the federal granting councils are not obligated to ensure research investment in all regions of the country, this is clearly in the spirit of the CIHR Act (Government of Canada 2000) and was a fundamental consideration in both the establishment of $\mathrm{RPP}^{2}$ and its continuation. ${ }^{3}$

- The investments made through this program have resulted in substantial long-term gains and leveraged dollars beyond the initial investments (CIHR 2007). Researchers have continued to succeed in bringing external research dollars to each of the provinces, from grants fully funded by CIHR or the other granting councils, the Canada Foundation for Innovation, Genome Canada, the health charities and a variety of international funding opportunities. From the perspective of the provinces, this program has been important in leveraging funds; much of the funding was directed towards salary support for highly qualified personnel.

- The provinces, through RPP, have been able to support health research of regional importance that meets national scientific merit as judged by peer review. This has resulted in support for biomedical and clinical research as well as research in health policy, service delivery and social and population health, which are of immediate importance to healthcare practice within the province. Examples of the research supported by RPP, from each of the six provinces, can be found at the CIHR website (CIHR 2009). The impact of RPP-funded studies, like other research, may be immediately apparent and have long-term benefits. For example, a study that received national attention (Abraham 2008), and which identified the genetic basis of a lethal sudden cardiac disease in a Newfoundland population, was supported through early RPP funding. The knowledge from the basic biomedical research (Merner et al. 2008) was utilized to provide screening for a population at risk for this lethal disease. The study provided an opportunity for people who tested positive to be identified and treated. For others, identified as non-carriers, early screening has removed the burden of not knowing. The program has had a direct benefit on many families and an impact on delivery of services (Hodgkinson et al. 2009).

+ As a result of RPP, a valuable collaboration has been developed across the provinces to discuss and address administrative policies in health research support. As part of the program, the chairs and funding partners of each provincial program met annually, providing an opportunity to discuss and exchange best practices and lessons learned at the administrative level.

\section{Concluding Thoughts}

MRC and CIHR are to be commended for initiating and supporting this program over the years. A formal review of RPP took place in 2004-2005, and an attempt was made to evaluate the program against its initial objectives (CIHR 2007). As such, the evaluation team was able to demonstrate substantial increases in research funding for researchers in the RPP provinces, 
which mirrored the overall increase in funding to the research community in Canada following the establishment of CIHR. Although the results did not indicate that the actual research funding reached the desired per capita funding rate, RPP has helped CIHR meet its mandate by increasing the overall number of health research grants funded in the regions.

Whether the loss of RPP will have a negative impact on regional health research, in particular given the ongoing changes in funding opportunities at CIHR (2014), remains to be seen. However, RPP has demonstrated how a relatively small federal investment can make valuable and significant contributions to scientific knowledge and to training the next generation of scientists and health professionals. The program has contributed to an increased involvement of the provinces in the health research enterprise. It has provided an important example of how the health research enterprise can be enhanced through encouraging partnership and leveraging investment.

\section{Acknowledgements}

Contributions to this paper were made by the following participants in the Regional Partnerships Program: Robert Bertolo, Department Biochemistry, Memorial University of Newfoundland; Jennifer McNutt, Nova Scotia Health Research Foundation; Roger Cole, New Brunswick Health Research Foundation; Leslie Cudmore, University of Prince Edward Island; Shannon Rogalski, Manitoba Health Research Council; and June Bold, Saskatchewan Health Research Foundation.

The author would also like to thank Dr. Ian Graham, School of Nursing, Faculty of Health Sciences, University of Ottawa, for his thoughtful input.

Dr. Moody-Corbett was the Chair of the NL-RPP Advisory Committee from 19992011 .

Correspondence may be directed to: Dr. Penny Moody-Corbett, 1416 Cavendish Rd., Ottawa, ON K1H 6C2; tel.: 613-680-6899; e-mail: pmoody@mun.ca.

\section{Notes}

1. Initially, MRC provided one-third of the funding and set a maximum investment of $\$ 500,000$ per province. However, with the advent of CIHR, the funding ratio was changed to $1: 1$ and the investment was increased per province to $\$ 1$ million. In addition, the provinces of New Brunswick and Prince Edward Island were included in the program, each being eligible for $\$ 200,000$.

2. "This situation raises the wider issue as to whether MRC, as a Federal Government Agency, has some social responsibility to ensure that a viable health research base is maintained in the different regions of the country" (Wood 1994).

3. "The other context to recognize is the belief that the presence of medical researchers in a region has a direct and positive impact on the quality of medical services available to the population of the region.... Given this belief, it follows that some minimal level of funding for health research should be maintained" (CIHR 2007). 


\section{References}

Abraham, C. 2008 (February 29). "Newfoundland's Sudden-Death Riddle Resolved." The Globe and Mail. Retrieved January 30, 2014. <http://www.theglobeandmail.com/life/newfoundlands-sudden-death-riddleresolved/article675761/>.

Canadian Institutes of Health Research (CIHR). 2007 (April 18). Summative Evaluation of the Regional Partnerships Program (RPP). Retrieved January 30, 2014. <http://www.cihr-irsc.gc.ca/e/31386.html>.

Canadian Institutes of Health Research (CIHR). 2009 (July 6). “The Stories Behind the Grants.” Retrieved January 30, 2014. <http://www.cihr-irsc.gc.ca/e/39272.html>.

Canadian Institutes of Health Research (CIHR). 2013 (January 18). "Regional Partnerships Program." Retrieved January 30, 2014. <http://www.cihr-irsc.gc.ca/e/46270.html>.

Canadian Institutes of Health Research (CIHR). 2014 (January)."2014 Foundation Scheme." Retrieved January 30, 2014. <http://www.cihr-irsc.gc.ca/e/44761.html>.

Government of Canada. 2000. Canadian Institutes of Health Research Act. S.C. 2000, c. 6. Retrieved January 30, 2014. <http://laws-lois.justice.gc.ca/eng/acts/C-18.1/FullText.html>.

Hodgkinson, K., E. Dicks, S. Connors, T.L. Young, P. Parfrey and D. Pullman. 2009.“Translation of Research Discoveries to Clinical Care in Arrhythmogenic Right Ventricular Cardiomyopathy in Newfoundland and Labrador: Lessons for Health Policy in Genetic Disease." Genetics in Medicine 11(12): 859-65.

Merner, N.D., K.A. Hodgkinson, A.F. Haywood, S. Connors, V.M. French, J.D. Drenckhahan et al. 2008. "Arrhythmogenic Right Ventricular Cardiomyopathy Type 5 Is a Fully Penetrant, Lethal Arrhythmic Disorder Caused by a Missense Mutation in the TMEM43 Gene." American Journal of Human Genetics 82(4): 809-21.

Wood, J.D. 1994. "Health Research Funding in Colleges of Medicine Located in Provinces with Relatively Small Populations." Saskatoon: University of Saskatchewan. 